\title{
Glucose-6-Phosphate Dehydrogenase Deficiency and Sickle Cell Hemoglobin among the Dhodias of Dadra Nagar Haveli
}

\author{
Mohd.Asghar and M.P.Sachdeva \\ Department of Anthropology, University of Delhi, Delhi 110 007, India \\ E-mail: *asghar2108@gmail.com,**<mpsachdeva@rediffmail.com>
}

KEYWORDS G6PD Deficiency. Sickle Cell Hemoglobin. Endogamous Tribe

\begin{abstract}
G6PD and sickle cell hemoglobin have been used as important markers in Anthropology. The present study deals with the screening of these markers among the Dhoidias, an endogamous tribe of Dadra Nagar Haveli. Out of the 74 males screened for G6PD deficiency, $13.5 \%$ of them are found to be deficient and out of 149 sample tested for sickle cell hemoglobin, $18.10 \%$ are found to have hemoglobin S (3.34\% have HbSS and $14.76 \%$ have $\mathrm{HbAS})$. The allele frequencies for $G D^{*}$ def and $H B * S$ were 0.135 and 0.107 , respectively.
\end{abstract}

\section{INTRODUCTION}

Glucose-6-Phosphate Dehydrogenase (G6PD) is an important enzyme (coded by a gene located at $\mathrm{Xq} 28$ ) in the pentose phosphate pathway, a metabolic pathway that supplies reducing energy to cells by maintaining the level of the co-enzyme nicotinamide adenine dinucleotide phosphate (NADPH). On the other hand, Sickle cell hemoglobin is an inherited condition characterized by defective hemoglobin (giving a sickle shape to red cells instead of circular) and the gene responsible for this defect is located on the short arm of chromosome 11 . Both have been used as important markers in Anthropology.

\section{MATERIAL AND METHODS}

Area and People: Dadra Nagar Haveli, which has an area of about $491 \mathrm{sq}$. $\mathrm{km}$. consists of two separate parts- Dadra and Nagar Haveli. Dadra is surrounded by the state of Gujarat and Nagar Haveli is situated on the border of Maharashtra and Gujarat. Dadra consists of 3 villages and Nagar Haveli has the town of Silvassa and 68 villages. According to 2001 Census of India, its population is 220451 with the sex ratio of 810.9 females per 1000 males. Its literacy rate is $60.03 \%$. Dhodias constitute $16.91 \%$ of the total population and are mostly settled in the northern part of this union territory. They are endogamous tribe practicing clan exogamy. They do not practice consanguineous marriages.

Methods: Blood samples were collected from 149 individuals (75 females and 74 males) in eppendorf tubes coated with 0.5M EDTA using the finger prick method in the month of January 2007. Special care was taken to avoid collection of samples from related individuals up to first cousin. Screening for G6PD deficient (males only) was done using fluorescent spot test (Beutler and Mitchell 1968). Sodium metabisulphite/ slide method (Daland and Castle 1948) was used to screen for sickle cell hemoglobin and for determining the zygosity agar gel electrophoresis method was used (Robinson et al. 1957). Allele frequencies for $G D * d e f$ and $H B * S$ were calculated using gene counting method and HardyWeinberg equilibrium was tested using $\chi^{2}$ goodness of fit test.

\section{RESULTS AND DISCUSSION}

In the present study, $13.5 \%$ of the male population is found to be G6PD deficient (Table $1)$. The earlier reported frequency for this population was $6.35 \%$ (Joshi et al. 1978). When comparing with the present data, it showed nonsignificant difference $\left(\chi^{2}=1.90, p=0.168\right.$, d.f. $=$ $1)$. It also showed non-significant difference with the two other tribes of this union territory - Varli $\left(\chi^{2}=1.15, p=0.283\right.$, d.f. $\left.=1\right)($ Joshi et al., 1978) and Konkanas $\left(\chi^{2}=0.31, \mathrm{p}=0.580\right.$, d.f. $\left.=1\right)($ Joshi et al. 1978). The gene frequency for $G D^{*}$ def is 0.135 . The frequency is also well within the reported range of western region, i.e. 0.000 to 0.196 (Bhasin 2006).

All 149 samples were tested for hemoglobin $\mathrm{S}(\mathrm{HbS}) .18 .10 \%$ were found to have hemoglobin S $(3.34 \%$ were homozygous and $14.76 \%$ were heterozygous) (Table 2). The population is in 
Table 1: Distribution of G6PD deficiency among Dhodias (Males) of Dadra Nagar Haveli.

\begin{tabular}{|c|c|c|c|c|c|}
\hline \multirow{2}{*}{$\begin{array}{l}\text { No. } \\
\text { test- } \\
\text { ed }\end{array}$} & \multicolumn{2}{|c|}{ Normal } & \multicolumn{2}{|c|}{ Deficient } & \multirow{2}{*}{$\begin{array}{c}\text { Allele frequency } \\
G D^{*} \text { def. }\end{array}$} \\
\hline & No. & $\begin{array}{c}\text { Per- } \\
\text { centile }\end{array}$ & No. & $\begin{array}{l}\text { Per- } \\
\text { centile }\end{array}$ & \\
\hline 74 & 64 & 0.865 & 10 & 0.135 & 0.135 \\
\hline
\end{tabular}

Table 2: Distribution of sickle cell Hemoglobin among the Dhodias of Dadra Nagar Haveli.

\begin{tabular}{lrccc}
\hline & No. & Percentile & \multicolumn{2}{c}{ Allele frequency } \\
\hline AS & 22 & 0.148 & $H B^{*} A$ & 0.893 \\
SS & 5 & 0.033 & $H B^{*} S$ & 0.107 \\
AA & 122 & 0.819 & & \\
\hline Total & 149 & 1.000 & & 1.000 \\
\hline
\end{tabular}

Hardy-Weinberg equilibrium with respect to $\mathrm{HbS}$ $\left(\chi^{2}=3.510,0.10<p<0.05\right.$, d.f. $\left.=1\right)$. An earlier study (Joshi et al. 1978) had reported a frequency of $21.53 \%$ for this population. In comparison with the present data, it shows non-significant difference $\left(\chi^{2}=0.341, p=0.559\right.$, d.f. $\left.=1\right)$. It also shows non-significant difference with Dhodias of Surat district $\left(\chi^{2}=0.005, \mathrm{p}=0.945\right.$, d.f. $\left.=1\right)$ (Vyas et al. 1962) and of Bulsar district $\left(\chi^{2}=0.878\right.$, $\mathrm{p}=0.349$, d.f. $=1)$ of Maharashtra (Negi 1976). $H B * S$ frequency was found to be 0.107 , which also lies within the earlier reported range of the western region, i.e. 0.000 to 0.167 (Bhasin 2006).

The observed increase in the frequency with respect to G6PD deficiency and decrease in case of sickle cell hemoglobin, in the presently studied population, as compared to previous data on the same population, about a generation ago is not statistically significant $\left(\chi^{2}=1.90, p=0.168\right.$, d.f. $=1$ and $\chi^{2}=0.341, \mathrm{p}=0.559$, d.f. $=1$ respectively). However, the Dhodias of Dadra Nagar Haveli need special health care regarding the two selected genetic disorders.

\section{ACKNOWLEDGEMENT}

We are very thankful to the Department of Anthropology, University of Delhi for funding our field trip to Dadra Nagar Haveli. Our special thanks to Dr. K.N. Saraswathy for her guidance and cooperation in completing this paper. We are also thankful to the people of Dhodias of Dadra Nagar Haveli for their cooperation.

\section{REFERENCES}

Beutler E, Mitchell M 1968. Special modification of the fluorescent screening method for glucose-6phospahte dehydrogenase deficiency. Blood, 32: 816-818.

Bhasin MK 2006. Genetics of castes and tribes of India: Glucose-6-Phosphate Dehydrogenase deficiency and Abnormal Hemoglobin ( $\mathrm{HbS}$ and $\mathrm{HbE}$ ). Int $J$ Hum Genet, 6(1): 19-72.

Daland GA, Castle WB 1948. A simple and rapid method for demonstrating sickling of red blood cells - the use of reducing agent. J Lab Clin Med, 33(9): 10821088.

Joshi SR, Mehta MM, Mehta DM, Bapat JP, Baxi AJ, Bhatia HM 1978. Genetic studies in three tribal groups of Dadra and Nagar Haveli region in western India. Ind J Phys Anthrop Hum Genet, 4: 133-140.

Negi RS 1976. Population Dynamics of Sickle Cell Trail Distribution in India. Ph.D. Thesis, Calcutta: University of Culcutta.

Robinson AR, Robson M, Harrison AP, Zuflzer WW 1957. A new technique for differentiation of hemoglobin. J Lab Clin Med, 50(5): 745-752.

Vyas GN, Bhatia HM, Sukumaran PK, Balakrishnan V, Sanghvi LD 1962. Study of blood group abnormal Haemoglobins and other genetical Characters in some tribes of Gujarat. Am J Phys Anthrop, 20: 255-265. 